\title{
Antihyperlidemic Effects of Mangosteen (Garcinia mangostana L.) Pericarp Ethanolic Extract in High-Carbohydrate Wistar Rats
}

\author{
Alkilany Salem Abuzaid*, Elin Yulinah Sukandar, Neng Fisheri Kurniati and I. Ketut Adnyana \\ Bandung Institute of Technology, School of Phrmacy, Bandung-40132, \\ Indonesia
}

\begin{abstract}
Garcinia mangostana L.has been used as an antioxidant to inhibit oxidation of low density lipoproteins and as an antiobesity agent. The aim of this study was to evaluate the effect of a Mangosteen (G. mangostana L.) Pericarp Ethanolic Extract (MPEE) on lipid profile in rats fed with high-fat diet.The experimental study was conducted in male Wistar rats for 4 weeks and 9 weeks, with rats divided into 5 treatment groups which were normal (standard diet), control (high-fat diet), dose 1 (high-fat diet, MPEE $200 \mathrm{mg} / \mathrm{kg}$ b.w.), dose 2 (high-fat diet, MPEE $500 \mathrm{mg} / \mathrm{kg} \mathrm{b.w.),} \mathrm{and} \mathrm{orlistat} \mathrm{(high-fat}$ diet, orlistat $21.6 \mathrm{mg} / \mathrm{kg}$ b.w.) groups. The serum concentration of cholesterol High Density Lipoprotein (HDL) and Low Density Lipoprotein (LDL) and triglycerides of all the animals in each group were determined after the 4 weeks and 9 weeks of treatment. Intrygliceride level, MPEE at the dose of $500 \mathrm{mg} / \mathrm{kgbw}$ was more active than the dose of $200 \mathrm{mg} /$ $\mathrm{kg}$. The rats treated with MPEE significantly decreased the LDL level in the 9 weeks at the dose of $200 \mathrm{mg} / \mathrm{kg}$ bw and 500 $\mathrm{mg} / \mathrm{kg}$ bw. However, the HDL level amongthe all groups showed no significant difference.Mangosteen Pericarp Ethanolic Extract (MPEE) has potential as anti-obesity drugs by lowering the tryglyceride and LDL level in high-fat Wistar rats.
\end{abstract}

Keywords: Mangosteen, Obesity, Triglyceride, HDL, LDL

\section{Introduction}

Obesity is well-known to contribute to the health impairment and several diseases such as work disability, sleep apnea, cardiovascular disease, cancer, type 2 diabetes mellitus, and osteoarthritis ${ }^{1}$. It was estimated that 3.4 million deaths in the year 2010 were caused by overweight and obesity ${ }^{2}$. Furthermore, obesity could lead to the decrease of life quality.
Obesity is associated with several established Atherosclerotic Cardiovascular Diseases (ASCVD) risk factors. One of the metabolic defects to appear in obese individuals, which is central to the pathway of ASCVD is, dyslipidemia ${ }^{3,4}$. Dyslipidemia is also one of the most prevalentmetabolic impairments in obesity, occurring in almost $60 \%$ of abdominally obese subjects, and also one of the strongest ASCVD risk factors in obesity ${ }^{3-5}$. The characteristic dyslipidemia of obesity is the atherogenic dyslipidemia, which is a triad of lipoprotein

*Author for correspondence 
disorders including: elevated serum triglycerides, high serum numbers of pro-atherogenic LowDensity Lipoprotein (LDL) particles, and low concentrations of athero-protective High-Density Lipoprotein Cholesterol (HDL-C) $)^{6,3-5}$. Thus, the prevention and treatments for obesity are urgently needed $^{1,2}$.

Various ways for effective therapy in obesity has been proposed, such as suppression on food intake, stimulation to energy expenditure, lipase inhibition, regulation on lipid metabolism, and inhibition of adipocyte differentiation ${ }^{7,8}$. Orlistat and acarbose are commercial drugs that commonly used as anti-obesity medications, but it has adverse effects ${ }^{9}$. Therefore, the usage of natural products that relatively safe as alternative therapy is much preferred ${ }^{10}$.

Mangosteen (Garcinia mangostana Linn), which is presumably originated from Southeast Asia, has long over the years been used as traditional remedies in several countries such as Sri Lanka, Malaysia, Philippines, Thailand, and India ${ }^{11}$. The thick mangosteen rind is usually used to treat some health disorder such as cystitis, diarrhea, dysentery, eczema, fever, intestinal ailments, and other skin ailments ${ }^{12,13}$. Mangosteen pericarp contains numerous polyphenolic acids such as xanthones and tannins. Xanthones from mangosteen have been widely studied for its medicinal properties; several known activities from xanthones are antioxidant, antitumor, anti-inflammatory, antiallergy, antibacterial, antifungal, and antiviral ${ }^{11,14}$.

In accordance with other studies, high-fat diet could induce obesity, hyperinsulinemia, and hyperglycemia, as well as lobular inflammation, hepatocyte necrosis in the liver of rats ${ }^{15}$. The sodium salt of glutamate (Monosodium Glutamate; MSG) commonly used as a flavoring agent, has been associated MSG use with obesity and aberrations in fat metabolism ${ }^{16}$. In the present study, the Mangosteen Peel Extracts (MPEE) were evaluated as well as controlled lipid profil through lowering level triglyceride level, LDL, and HDL cholesterol level on wistar rats induced by MSG and high-fat diet.

\section{Materials and Methods}

\subsection{Mangosteen Pericarp Ethanolic Extracts Preparation}

The mangosteen (MPEE) fruit was obtained from IndonesianfarmsinCicantayan,Sukabumi,Bandung, West Java, Indonesia. The plants were identified by the herbarium staff from Departement of Biology, School of Life Science and Technology, Bandung Institute of Technology, Bandung, Indonesia. The pericarp was collected from mangosteen fruit, then dried and ground into small pieces. Subsequently, it was extracted using reflux method in water and $50 \%$ of ethanol. The extract is then freeze-dried and MPEE in dried powder form was produced ${ }^{17,18}$.

\subsection{Experimental Design}

The study was conducted at the Laboratory of Experimental Animals, School of Pharmacy, Bandung Institute of Technology, Bandung, Indonesia.The methods related to the use of animals in this study have been approved by Ethical Commission, School of Pharmacy, Bandung 
Institute of Technology with ethical approval number 05/KEPHP-ITB/05-2015.

The Twenty-five male Wistar rats with the age of 4 weeks, with the weight in the range of 90 to 110 grams were used. All rats were kept under standard environment for laboratory animals. Prior to the treatment, they were acclimatized for 7 days by giving the normal food and water. Subsequently, the rats were divided randomly into five groups namely normal, control, dose 1, dose 2, and orlistat group. The normal group was given CMC-Na 0.5\% (0.05 $\mathrm{g} / \mathrm{kg}$ ) solution, the control group was not given any treatment, the dose 1 group was given MPEE (200 $\mathrm{mg} / \mathrm{kg}$ rat bw.), the dose 2 group was given MPEE (500 mg/kg rat bw.), and the orlistat group was given orlistat (Xenical) $(21.67 \mathrm{mg} / \mathrm{kg}$ rat bw). For the first 5 days, all groups except the normal group were received MSG $2 \mathrm{mg} / \mathrm{kg}$ bw. through subcutaneous injection together with high-carbohydrate food to induce the obese condition, while the normal group was received standard diet. For 9 weeks, the normal group was continuously received standard diet while the other groups received high-carbohydrate food. The composition of the standard and highcarbohydrate food was in accordance to Adnyana et al. (2014) study with slight modification ${ }^{19}$. The rats were maintained daily and checked for the body weight changes during experiment period, total cholesterol, TG, LDL, HDL, feces and urine measure in the first week, week 4 and week 9. Twenty-four hours after the last day of the experiment, all rats were sacrificed using carbon dioxide. Following the euthanasia procedure the serum, perirenal and perianal fat were immediately isolated and stored in a freezer at the temperature of $-20^{\circ} \mathrm{C}$.

\subsection{Measurement of Total Cholesterol, Triacylglycerides, LDL and HDL after Administration of High Calorie Diet}

The cholesterol is determined after enzymatic hydrolysis and oxidation. The indicator quinoneimine is formed from hydrogen peroxide and 4-aminophenazone in the presence of phenol and peroxidase. The enzyme reagent and the standard are ready for use. The reagents are stable up to the given expiry date, even after opening, when stored at 2 to $8^{\circ} \mathrm{C}$, and it could stay up to 2 weeks at 15 to $25^{\circ} \mathrm{C}$. The samples used is serum. High Density Lioprotein (HDL) cholesterol is a direct homogeneous enzymatic assay for quantitative determination of HDL cholesterol. High Density Lioprotein (HDL) is regarded to protect lipid component against Coronary Heart Disease $(\mathrm{CDH})$. During preventive time in vivo method, total cholesterol, HDL, LDL, triglyceride, were measured in the beginning or before being induced week 4 and week 9 . In the first week or before being induced, the total cholesterol, HDL, LDL, triglyceride, were started without any changes between groups or variables, otherwise, all groups were started in zero condition.

\subsection{Statistical Analysis}

All data are expressed as mean \pm SD. The difference between groups were compared by one-way ANOVA followed by an LSD post hoc test. An associated probability ( $\mathrm{P}$ value) below $0.05 \%$ was considered as significant.

\section{Results}

An imbalance between caloric intake and energy expenditure results in excessive storage of corporal 


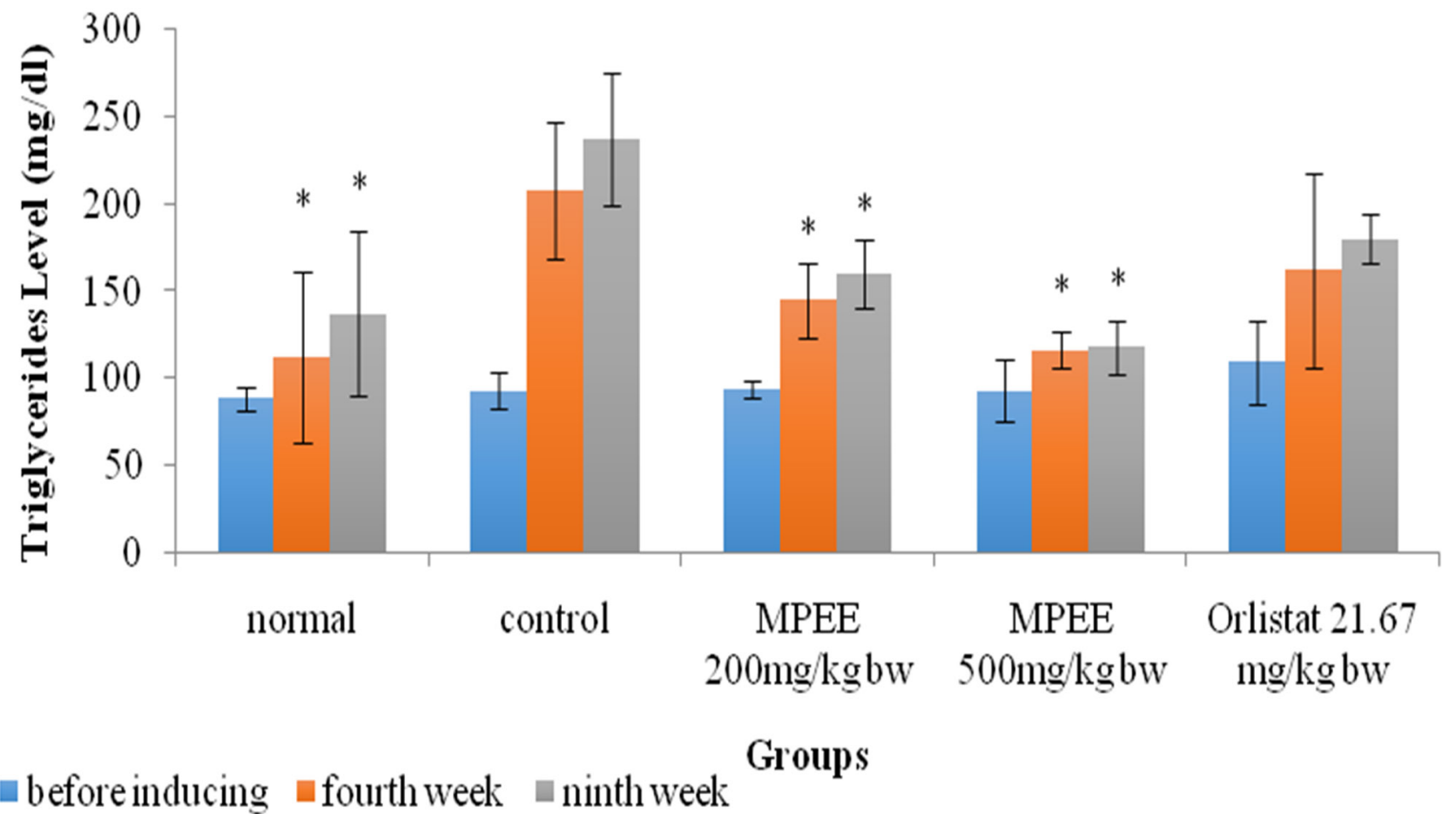

Fig. 1. Triglyceride level in blood serum of MSG-high carbohydrate food induced obese rats treated with MPEE between groups before inducing, in the fourth week and ninth week of treatment.

The $\left({ }^{*}\right)$ marks indicate significant differences compared to the control group (LSD post hoc test; ${ }^{*}=p<0.05$ ).

fat, often resulting in overweight or obesity. This imbalance often produces an altered lipid profile characterized by high triglycerides (TG) serum levels, high total cholesterol, high LDL-cholesterol, and low levels of HDL-cholesterol that increases the risk of cardiovascular disease (CAD) ${ }^{20}$.

In Figure 1, before thetreatment, the TG level showed no difference among all the groups. In the week 4 and week 9 after treatment, there were significantly different in TG level between the control and normal groups. The control group showed no significant differencecompared to the orlistat group, while MPEE at dose of $200 \mathrm{mg} / \mathrm{kg}$ bw and $500 \mathrm{mg} / \mathrm{kg}$ bw had significant difference compared to control group, especially MPEE at dose of $500 \mathrm{mg} / \mathrm{kg}$ bw which was more effective than the dose of $200 \mathrm{mg} /$ $\mathrm{kg}$ bw in lowering TG level.

In Figure 2, before the treatment and in the week 4 , there was no difference in LDL cholesterol among the all groups. In the week 9 MPEE at the dose of $200 \mathrm{mg} / \mathrm{kg} / \mathrm{bw}$ and the dose of $500 \mathrm{mg} / \mathrm{kg} / \mathrm{bw}$ had a significant difference compared to the control group of cholesterol level.

As shown in Figure 3, there was no difference in HDL-C level between the all groups in the week 4 


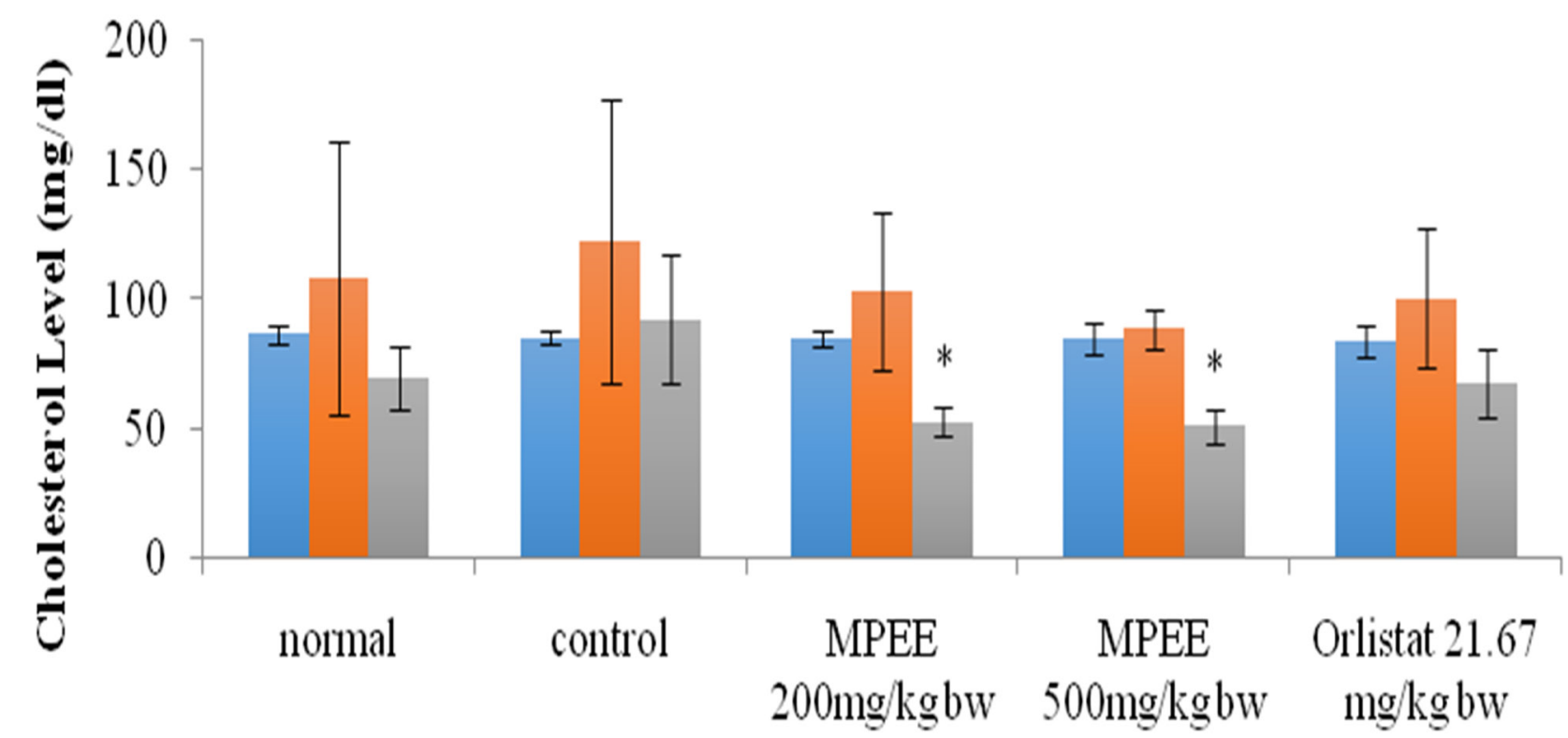

\section{- before inducing $\square$ foutth week $₫$ ninth week}

\section{Groups}

Fig. 2. LDL cholesterol level in blood serum of MSG-high carbohydrate food induced obese rats treated with MPEE between groups before inducing in the fourth week and ninth week.

The $\left(^{*}\right)$ marks indicate significant differences compared to the control group (LSD post hoc test; ${ }^{*}=p<0.05$ ).

and week 9, which means there was no effects from MPEE.

\section{Discussion}

Obesity has become a global concern over the years which rapidly increasing and it is often associated with several diseases such as cardiovascular disease, cancer, and type 2 diabetes mellitus ${ }^{21,22}$. Anti obesity drugs that are efficacious and have minimal side effects are therefore urgent ${ }^{23}$. In this study, we observed the MPEE abilities to prevent the obesity as well as the pathogenesis of metabolic syndrome, by measuring the triglycerides, LDL and $\mathrm{HDL}$ cholesterol level.
Consumption of long-chain saturated fatty acids $(\mathrm{C}>10)$ generates increases in cholesterol and triglyceride levels ${ }^{24,25}$. In this study, MPEE significantly reduced triglyceride levelsat both doses compared to the control and orlistat (standard drug). Our previous study showed MPEE have great potential as a therapeutic agent in preventing obesity by suppressing major body weight gain and reducing FAS concentration ${ }^{26}$. The other study showed that MPEE has the ability to lower the lipid droplet in the liver, especially MPEE with the concentration of $200 \mathrm{mg} / \mathrm{kg}$ bw. It also revealed that the treatments of MPEE were able to decrease the toxicity effect of obesity-induced condition (high-fat diet) toward the liver, further demonstrating that MPEE have a 


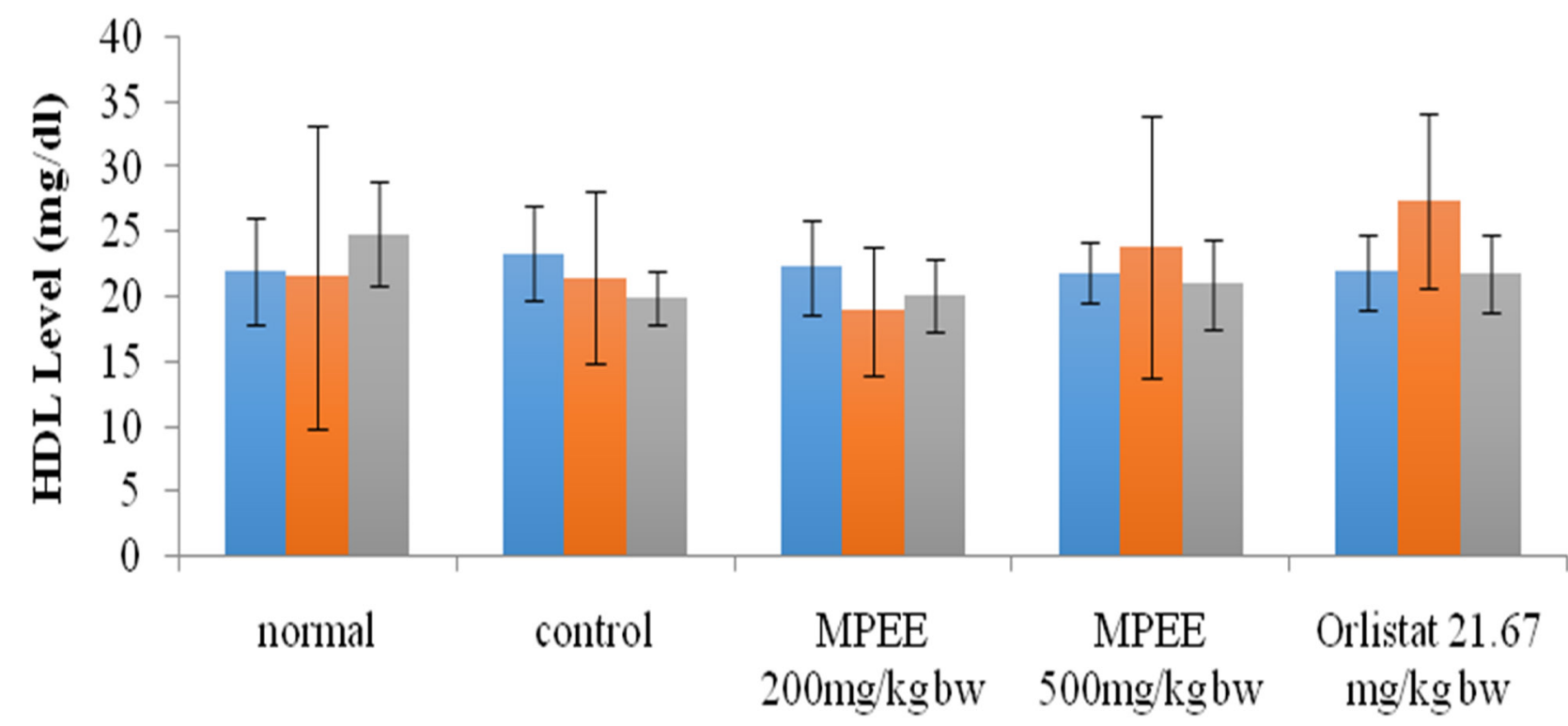

before inducing $\square$ fourth week $₫$ ninth week

\section{Groups}

Fig. 3. HDL level in blood serum of MSG-high carbohydrate food induced obese rats treated with MPEE between groups before inducing in the week 4 and 9.

beneficial effect toward metabolic syndrome that often connected with obesity ${ }^{18}$.

Increased triglyceride leads to increases in LDL levels which is necessary for transporting the cholesterol to peripheral tissues for oxidation or to adipose tissues for storage ${ }^{27}$. Increases in triglyceride levels also lead to increases in chylomicron and Very Low Density Lipoprotein (VLDL) levels, as transporters of triglycerides. Low Density Lipoproteins (LDL) is the last stage of VLDL catabolism, which therefore raised VLDL levels and increase LDL levels. Increased cholesterol levels result in down regulation of native LDL receptors ${ }^{28}$. In the present study,lowest LDL levelwas obtained from treatment of MPEE at 9 weeks compared to control and orlistat. Mangosteen Pericarp Ethanolic Extracts (MPEE) has been previously reported in several studies to inhibit cholesterol formation process $^{19,29,30}$.

In the present study, there was no difference in HDL level between all the groups in the week 4 and week 9 that indicated MPEE was not effective increasing of HDL level.In contrary, previous study showed the HDLlevels, starting at a dosage of $200 \mathrm{mg} /$ $\mathrm{kg} \mathrm{bw}^{29}$. Metabolic abnormalitiespresent in obese states may indirectly cause thelowering of HDL2 levels in obese individuals. Hypertriglyceridemia,in particular, is frequently associated withreduced HDL levels and enhanced HDL catabolism in obesesubjects $^{31}$. In hypertriglyceridemic states, such as obesity,the plasma protein, Cholesteryl 
Ester Transfer Protein (CETP), mediates a greater net transfer of triglycerides from the triglyceride rich lipoproteins (VLDLs and chylomicrons) to HDL particles than normal ${ }^{32}$.

\section{Conclusion}

The Mangosteen Pericarp Ethanolic Extract (MPEE) significantly reduces trygliceride and LDL cholesterol, which makes its potential as anti-obesity drugs. However, MPEE does not significantly increase the HDL cholesterol. Further, clinical and toxicology studies are encouraged.

\section{Acknowledgement}

This research was supported by Biomolecular and Biomedical Research Center, Aretha Medika Utama, Bandung, Indonesia for laboratory facilities, and research methodology.

\section{References}

1. Seidell JC, Halberstadt J. The global burden of obesity and the challenges of prevention. Ann Nutr Metab. 2015; 66(2):7-2. Crossref. PMid:26045323

2. Ng M, Fleming T, Robinson M, Thomson B, Graetz $\mathrm{N}$, Margono C et al. Global, regional, and national prevalence of overweight and obesity in children and adults during 1980-2013: A systematic analysis for the global burden of disease study 2013. Lancet. 2014; 384(9945):766-1. Crossref.

3. Konturek SJ, Konturek JW, Pawlik T, Brzozowski T. Brain-gut axis and its role in the control of food intake. J Physiol Pharmacol. 2004; 55(1 Pt 2):137-4. PMid:15082874
4. Nawrot-Porabka K, Jaworek J, Leja-Szpak A, Palonek M, Szklarczyk J, Konturek SJ. Leptin Is able to stimulate pancreatic enzyme secretion via activation of duodeno-pancreatic reflex and cck release. J Physiol Pharmacol. 2004;55:47-7. PMid:15608360

5. Schwartz MW, Woods SC, Porte D Jr, Seeley RJ, Baskin DG. Central nervous system control of food intake. Nature. 2000; 404(6778):661-1. Crossref. PMid:10766253

6. Bajari TM, Nimpf J, Schneider WJ. Role of leptin inreproduction. J Curr Opin Lipido. 2004; 15:315-9. Crossref.

7. Yun J. Possible anti-obesity therapeutic from nature-a review. Phytochem. 2010; 71(14-15):1625-1. Crossref. PMid:20732701

8. Widowati W, Darsono L, Suherman J, Fauziah N, Maesaroh M, Erawijantari PP. Anti-inflammatory effect of mangosteen (Garcinia mangostana L.) peel extract and its compounds in LPS-induced RAW 264.7 Cells. Nat Prod Sci. 2016; 22(3):147-3. Crossref.

9. Kang J, Park C. Anti-obesity drugs: A review about their effects and safety. Diabetes Metab J. 2012; 36:13-5. Crossref. PMid:22363917 PMCid: PMC3283822

10. Liu Q, Wang Y, Lin L. New insights into the antiobesity activity of xanthones from Garcinia mangostana. Food Funct. 2015;6:383-3. Crossref. PMid:25520256

11. Pedraza-Chaverrí J, Cárdenas-Rodríguez N, OrozcoIbarra M, Pérez-Rojas JM. Medicinal properties of mangosteen (Garcinia mangostana). Food Chem Toxicol. 2008; 46:3227-9. Crossref. PMid: 18725264

12. Akao Y, Nakagawa Y, Iinuma M, Nozawa Y. Anticancer effects of xanthones from pericarps of mangosteen. Int J Mol Sci. 2008; 9:355-70. Crossref. PMid:19325754 PMCid:PMC2635669 
Antihyperlidemic Effects of Mangosteen (Garcinia mangostana L.) Pericarp Ethanolic Extract in High-Carbohydrate Wistar Rats

13. Cui J, Hu W, Cai Z, Liu Y, Li S, Tao W et al. New medicinal properties of mangostins: Analgesic activity and pharmacological characterization of active ingredients from the fruit hull of Garcinia mangostana L. Pharmacol Biochem Behav. 2010; 95:166-2. Crossref. PMid:20064550

14. Widowati W, Darsono L, Suherman J, Yelliantty Y, Maesaroh M. High Performance Liquid Chromatography (HPLC) analysis, antioxidant, antiaggregation of mangosteen peel extract (Garcinia mangostana L.). Int J Biosci Biochem Bioinform. 2014; 4(6):458-6. Crossref.

15. Larter CZ, Yeh MM. Animal models of NASH: Getting both pathology and metabolic context right. J Gastroenterol Hepatol. 2008; 23:1635-8. Crossref. PMid:18752564

16. Brosnan JT, Drewnowski A, Friedman M.I. Erratum to: Is there a relationship between dietary MSG and obesity in animals or humans? Amino Acid. 2014; 46(9):2089-9. Crossref. PMid:24927698

17. Shibata $M$, Iinuma $M$, Morimoto J, Kurose $H$, Akamatsu K, Okuno Y, et al. a-Mangostin extracted from the pericarp of the mangosteen (Garcinia mangostana Linn) reduces tumor growth and lymph node metastasis in an immunocompetent xenograft model of metastatic mammary cancer carrying a p53 mutation. BMC Med. 2011; 9(69):1-8.

18. Abuzaid AS, Iskandar EY, Kurniati NF, Adnyana IK. Prevention of obesity and development of metabolic syndrome by mangosteen (Garcinia mangostana L.) pericarp ethanolic extract in male wistar rats fed with high-fat diet. IJPPS. 2016a; 8(5): $1-7$.

19. Adnyana IK, Abuzaid AS, Iskandar EY, Kurniati NF. Pancreatic lipase and $\alpha$-amylase inhibitory potential of mangosteen (Garcinia mangostana Linn.) pericarp extract. Int J Med Res Health Sci. 2016; 5(1):23-8. Crossref.
20. Hu D, Hannah J, Gray RS, Jablonski KA, Henderson JA, Robbins DC, et al. Effects of obesity and body fat distribution on lipids and lipoproteins in nondiabetic American Indians: The strong heart study. Obes Res. 2000; 8(6):411-1. Crossref. PMid:11011907

21. Bray GA. Obesity: The disease. J Med Chem. 2006; 49(14):4001-7. Crossref. PMid:16821759

22. Lois K, Kumar S. Obesity and diabetes. Endocrinol Nutr. 2009; 56(4):38-2. Crossref.

23. Kang J, Nam D, Kim K, Huh J, Lee J. Effect of Gambisan on the inhibition of adipogenesis in 3T3L1 adipocytes. J Evid Based Complementary Altern Med. 2013; 2013:1-1. Crossref. PMid:23589718 PMCid:PMC3622388

24. Lee YJ, Choi DH, Cho GH, Kim JS, Kang DG, Lee HS. Arctium lappa ameliorates endothelial dysfunction in rats fed with fat/cholesterol diets. BMC Compl Altern Med. 2012;12:116-5. Crossref. PMid:22866890 PMCid:PMC3517347

25. e Silva MAA, Vechetti-Junior IJ, do Nascimento AF, Furtado KS, Azevedo L, Ribeiro DA et al. Effects of swim training on liver carcinogenesis in male Wistar rats fed a low-fat or high-fat diet. Appl Physiol Nutr Metab. 2012; 37:1101-9. Crossref. PMid:22957766

26. Abuzaid AS, Iskandar EY, Kurniati NF, Adnyana IK. Preventive effect on obesity of mangosteen (Garcinia mangostanaL.) pericarp ethanolic extract by reduction of fatty acid synthase level in monosodium glutamate and high-calorie diet-induced male wistar rats. Asian J Pharm Clin Res. 2016; 9(3):257-60.

27. Edwar Z, Suyuthie H, Yerizel E, Sulastri D. Pengaruh pemanasan terhadap kejenuhan asam lemak minyak goreng sawit dan minyak goreng jagung. J Indonesian Med Assoc. 2011; 61(6):248-2.

28. McLaren JE, Michael DR, Ashlin TG, Ramji DP. Cytokines, macrophage lipid metabolism and foam cells: Implications for cardiovascular disease 
therapy. Prog Lipid Res. 2011; 50(4):331-7. Crossref. PMid:21601592

29. Adiputro DL, Widodo MA, Romdoni R, Sargowo D. Extract of mangosteen increases high density lipoprotein levels in rats fed high lipid. Universa Medicina. 2013; 32(1):37-3.

30. Wihastuti TA, Widodo MA, Heriansyah T, Sari NAK. Study of the inhibition effect of ethanolic extract of mangosteen pericarp on atherogenesis in hypercholesterolemic rat. Asian Pac J Trop Dis. 2015; 5(10):830-4. Crossref.

31. Rashid S, Genest J. Effect of obesity on high-density lipoprotein metabolism. Obese. 2007; 15(12):28758. Crossref. PMid:18198293

32. Barter PJ, Kastelein JJP. Targeting cholesteryl ester transfer protein for the prevention and management of cardiovascular disease. 2006; 47(3):492-9. 